\title{
Hubungan Konsep Diri dengan Minat Wirausaha pada Mahasiswa Universitas Medan Area
}

\author{
Syafrizaldi \\ Fakultas Psikologi, Universitas Medan Area, Indonesia
}

Diterima: Desember 2018; Disetujui: Desember 2018; Dipublish: Desember 2018

E-mail: syaf.rizaldi.csr@gmail.com

\begin{abstract}
Abstrak
Dalam penelitian ini peneliti ingin melihat bagaimana korelasi antara konsep diri dengan minat wirausaha pada Mahasiswa Universitas Medan Area. Setelah dilakukan analisis data statistik terlihat hahwa konsep diri dengan minta memiliki korelasi yang signifikan. Hasil statistik menunjukkan bahwa Rx1y $=0.454, p<0.010$, yang artinya bahwa ada korelasi signifikan antara kedua variable tersebut, dengan pengertian bahwa semakin baik konsep diri maka semakin tinggi pula minat wirausaha pada mahasiswa dan juga demikian sebaliknya. Adapun koefisien determinan $\left(\mathrm{r}^{2}\right)$ dari korelasi antara konsep diri dengan minat wirausaha adalah sebesar $r^{2}=0,206$. Hal ini menunjukkan bahwa minat wirausaha dibentuk oleh konsep diri sebesar 20,6\%,
\end{abstract}

Kata Kunci : Minat Wirausaha, Konsep Diri

\begin{abstract}
In this study the researchers wanted to see how the correlation between self-concept and entrepreneurial interest in Medan Area University Students. After analyzing the statistical data, it appears that the selfconcept by asking has a significant correlation. Statistical results show that Rx1y $=0.454, p<0.010$, which means that there is a significant correlation between the two variables, with the understanding that the better the self concept, the higher the entrepreneurial interest in students and vice versa. The determinant coefficient ( $r 2$ ) from the correlation between self-concept and entrepreneurial interest is equal to $r 2=$ 0.206 . This shows that entrepreneurial interest is formed by self-concept of $20.6 \%$,
\end{abstract}

Keywords: Entrepreneurial Interest, Self Concept

How to Cite: Syafrizaldi. (2018). Hubungan Konsep Diri dengan Minat Wirausaha pada Mahasiswa Universitas Medan Area. Journal of Education, Humaniora and Social Sciences (JEHSS). 1 (2): 75-80.

\section{PENDAHULUAN}

Mencermati bahwa kenyataan yang ada jumlah pengangguran terjadi dewasa ini mengalami peningkatan. Data yang baru saja dilansir BPS menyatakan, angka pengangguran di Indonesia per Agustus 2013 melonjak 7,39 juta jiwa dari Agustus 2012 sebanyak 7,24 juta jiwa. Jika kita melihat juga kenyataan setiap tahunnya ribuan lulusan dari seluruh perguruan tinggi yang ada tidak mampu secara optimal diserap oleh pasar tenaga kerja dikarenakan keterbatasan lapangan pekerjaan yang ada saat ini.

Universitas Medan Area sebagai salah satu perguruan tinggi yang merupakan perguruan tinggi yang sudah cukup banyak melahirkan lulusan dari 7 fakultas dan beroperasi sejak tahun 1983. Disadari bahwa, tidak hanya UMA, sejumlah perguruan tinggi tentunya menginginkan agar lulusannya dapat bekerja dengan cepat, sesuai dengan latar belakang pendidikan, memiliki penghasilan yang sesuai dengan pendidikan, dan masa tunggu yang relative singkat untuk mendapatkan pekerjaan yang sesuai tersebut. Namun realitanya masih banyak para lulusan yang masih berstatus pengangguran dalam jumlah yang besar dan dalam kurung waktu yang relative lama.

Oleh karena itulah merupakan langkah yang sangat tepat jika Universitas Medan Area (UMA) memberikan perhatian terhadap fenomena ini dengan mensiasati suatu langkah pemecahan masalah yang ada di atas. Sehingga UMA memberikan perhatian khusus terhadap 
bagaimana menumbuhkan minat wirausaha pada mahasiswanya. Hal ini sejalan dengan tiga hal yang menjadi focus pengembangan mahasiswa di UMA yaitu; Kepribadian, Keilmuan dan Kewirausahaan.

Berwirausaha merupakan pilihan yang cerdas untuk menyikapi fenomena yang diutarakan di atas. Bagi individu yang berwirausaha memeliki keuntungan tersendiri yang tidak bisa dirasakan oleh mereka yang menjadi pegawai. Dengan memilih untuk menjadi wirausahawan berarti individu tidak tergantung dari lapangan pekerjaan, justru berwirausaha bisa menciptakan lapangan kerja bagi yang lainnya.

Namun dalam kenyataannya tidak banyak individu yang mau memilih menjadi wirausahawan. Hal ini mungkin disebabkan oleh kurangnya minat individu untuk berwirausaha. Minat adalah sikap yang membuat orang senang akan objek situasi tertentu. Hal ini diikuti oleh perasaan senang dan kecendrungan untuk mencari objek yang disenangi itu (As'ad, 1991).

Lebih lanjut bahwa Hurlock (1990) mengatakan bahwa minat merupakan aspek psikologis yang berpengaruh terhadap kesuksesan seseorang dalam melakukan tugasnya. Oleh karena itu seseorang yang memiliki minat kewirausahaan akan menaruh perhatian lebih dan mengarahkan segenap kemampuannya untuk mengusahakan terwujudnya kegiatan kewirausahaan tersebut karena merasa senang melakukannya. Winkel (2004), mengatakan bahwa minat diartikan sebagai kecenderungan subyek yang menetap, untuk tertarik pada bidang studi atau pokok bahasan tertentu dan merasa senang mempelajari materi itu. Jadi seorang yang memiliki minat kewirausahaan memiliki kecendrungan yang menetap tertarik pada bidang wirausaha dengan senang hati.

Minat dalam hal berwirausaha ini salah satu factor yang mempengaruhinya yaitu konsep diri sesuai dengan pendapat dari Crow\&Crow (1989) yang mengatakan bahwa minta dipengaruhi oleh kepercayaan diri kepribadian timbul di dalamnya adalah konsep diri, nilai-nilai moral dan factor perasaan, selain itu juga factor dari luar seperti jenis kelamin, dan tingkat pendidikan.

Berdasarkan pendapat ahli diatas minat berwirausaha salah satunya adalah konsep diri yang merupakan bagian dari sisi kepribadian yang ada pada seseorang. Konsep diri merupakan suatu bagian yang penting dalam setiap pembicaraan tentang kepribadian manusia. Konsep diri merupakan sifat yang unik pada manusia, sehingga dapat digunakan untuk membedakan manusia dari makhluk hidup lainnya. Menurut Burns (1982), konsep diri adalah hubungan antara sikap dan keyakinan tentang diri kita sendiri. Lebih lanjut Burn (1993) mengatakan konsep diri mempunyai peranan yang sangat besar dalam menentukan keberhasilan seseorang di bidang pekerjaannya, hal ini disebabkan karena konsep diri merupakan landasan bagi seseorang untuk terbuka dan peka terhadap perasaan-perasaan dari dalam dirinya, terhadap perasaan-perasaan dari orang lain dan terhadap realitas-realitas lingkungannya.

Konsep diri adalah semua persepsi terhadap aspek diri yang meliputi aspek fisik, aspek sosial, dan aspek psikologis, yang didasarkan pada pengalaman dan interaksi dengan orang lain (Sobur, 2003). Definisi sederhananya konsep diri merupakan keyakinan, pandangan atau penilaian seseorang terhadap dirinya (Rini, 2002). Konsep diri ini ada yang sifatnya positif dan ada yang negatif. Konsep diri positif adalah ketika seseorang mampu menghargai dirinya dan melihat hal-hal positif yang dapat dilakukannya demi keberhasilan dan prestasi. Sedangkan konsep diri negatif adalah ketika seseorang memiliki keraguan pada dirinya, memandang dirinya lemah, tidak dapat berbuat, tidak kompeten, gagal, tidak menarik, tidak disukai dan lain-lain yang berbau pesimistis (Ubaydillah, 2007).

Dapat dikatakan bahwa konsep diri suatu unsure dalam diri seseorang yang memberikan arah terhadap keberhasilan seseorang dalam melakukan segala sesuatu yang menjadi tujuannya. Termasuk juga dalam hal berwirausaha, bagaimana seseorang memiliki minat dalam hal membangun suatu usaha mandiri atau wirausaha secara mandiri. Sudah tentu seseorang yang memiliki konse diri yang positif akan mencapai keberhasilan dalam menjalankan minat wirausaha. Oleh karena itu peneliti dalam kesempatan ini tertarik untuk meneliti mengenai "Minat Wirausaha Ditinjau Dari Konsep Diri Pada Mahasiswa Universitas Medan Area". 


\section{METODE PENELITIAN}

Metode penelitian merupakan unsur yang paling penting di dalam suatu penelitian, karena dapat menentukan apakah penelitian tersebut dapat dipertanggungungjawabkan hasilnya atau tidak. Penelitian menggunakan pendekatan kuantitatif, menggunakan metode penelitian deskriptif korelasional.

Analisis yang dilakukan dalam melihat korelasi antar variable independent dan variable dependent dengan menggunakan analisis regresi (Anareg). Hasilnya bahwa ada hubungan yang signifikan antara konsep diri dengan minta wirausaha artinya bahwa konsep diri memberikan pengaruh terhadap minat wirausaha. Dengan asumsi bahwa semakin positif konsep diri maka akan semakin tinggi minat wirausaha pada mahasiswa. Hal ini ditinjau dari hasil koefisien Rxy sebesar $=0.454, \mathrm{p}<0.010$, yang artinya bahwa ada korelasi signifikan antara kedua variable tersebut, dengan pengertian bahwa semakin baik konsep diri maka semakin tinggi pula minat wirausaha pada mahasiswa dan juga demikian sebaliknya. Adapun koefisien determinan $\left(\mathrm{r}^{2}\right)$ dari korelasi antara konsep diri dengan minat wirausaha adalah sebesar $r^{2}=0,206$. Hal ini menunjukkan bahwa minat wirausaha dibentuk oleh konsep diri sebesar 20,6\%.

\section{HASIL DAN PEMBAHASAN Pengertian Minat wirausaha}

Menurut kamus lengkap psikologi, minat (interest) adalah (1) satu sikap yang berlangsung terus menerus yang memolakan perhatian seseorang, sehingga membuat dirinya jadi selektif terhadap objek minatnya, (2) perasaan yang menyatakan bahwa satu aktivitas, pekerjaan, atau objek itu berharga atau berarti bagi individu, (3) satu keadaan motivasi, atau satu set motivasi, yang menuntun tingkah laku menuju satu arah (sasaran) tertentu (Chaplin, 2008)

Minat adalah kesadaran individu terhadap sesuatu hal yang bersangkut paut dengan dorongan sehingga individu memusatkan seluruh perhatiannya terhadap objek tertentu dengan senang hati melakukan aktivitas yang berhubungan dengan objek (Crow \& Crow 1973 \& Strong, 1984). Minat merupakan faktor pendorong yang menjadikan seseorang lebih giat bekerja dan memanfaatkan setiap peluang yang ada dengan mengoptimalkan potensi yang tersedia. Minat tidak muncul begitu saja tetapi tumbuh dan berkembang sesuai dengan faktor-faktor yang mempengaruhinya (Walgito, 2003).

Pengertian wirausaha menurut pandangan psikologi adalah seseorang yang memiliki dorongan kekuatan untuk memperoleh suatu tujuan, suka mengadakan eksperimen untuk menampilkan kebebasan dirinya, di luar kekuasaan orang lain. Menurut Kamus Besar Bahasa Indonesia, wirausaha adalah orang yang pandai atau berbakat mengenali produk baru, menentukan cara produksi baru, menyusun operasi untuk mengadakan produk baru, mengatur permodalan operasinya serta memasarkannya

Wirausaha merupakan pelaku dari kewirausahaan, yaitu orang yang memiliki kreativitas dan inovatif sehingga mampu menggali dan menemukan peluang dan mewujudkan menjadi usaha yang menghasilkan nilai/laba. Kegiatan menemukan sampai mewujudkan peluang menjadi usaha yang menghasilkan disebut proses kewirausahaan. Kegiatan wirausaha adalah menciptakan barang jasa baru, proses produksi baru, organisasi (manajemen) baru, bahan baku baru, pasar baru. Hasil-hasil dari kegiatan-kegiatan wirausaha tersebut menciptakan nilai atau kemampu labaan bagi perusahaan. Kemampuan menciptakan nilai tersebut karena seorang wirausaha memiliki sifat-sifat kretaif dan inovatif.

Jadi dapat dikatakan bahwa minat wirausaha yaitu rasa tertariknya seseorang untuk melakukan kegiatan usaha yang mandiri dengan keberanian mengambil resiko. Minat tinggi berarti kesadaran bahwa wirausaha melekat pada dirinya sehingga individu lebih banyak perhatian dan lebih senang melakukan kegiatan wirausaha. 


\section{Faktor-Faktor Yang Mempengaruhi Minat Berwirausaha}

Crow \& Crow (1989) yang mengatakan bahwa minta dipengaruhi oleh kepercayaan diri kepribadian timbul di dalamnya adalah konsep diri, nilai-nilai moral dan factor perasaan, selain itu juga factor dari luar seperti jenis kelamin, dan tingkat pendidikan.

Minat seseorang terhadap suatu obyek diawali dari perhatian seseorang terhadap obyek tersebut. Minat merupakan sesuatu hal yang sangat menentukan dalam setiap usaha, maka minat perlu ditumbuh kembangkan pada diri setiap mahasiswa. Minat tidak dibawa sejak lahir, melainkan tumbuh dan berkembang sesuai dengan faktor-faktor yang mempengaruhinya. Adapun fakor Intrinsik, adalah faktor-faktor yang timbul karena pengaruh rangsangan dari dalam diri individu itu sendiri: 1) Pendapatan; 2) Harga Diri; 3) Perasaan Senang. Faktor Ekstrinsik, adalah faktor-faktor yang mempengaruhi individu karena pengaruh rangsangan dari luar: 1) Lingkungan Keluarga; 2) Lingkungan Masyarakat; 3) Peluang; 4) Pendidikan

Menurut Indarti (dalam Ritonga dan Afia Randa, 2011) Minat berwirausaha dipengaruhi oleh beberapa faktor diantaranya 1) karakteristik kepribadian, 2) faktor demografi dan 3) karakteristik lingkungan. Karakteristik kepribadian seperti: a) efikasi diri dan 2) kebutuhan akan prestasi merupakan prediktor yang signifikan minat berwirausaha. Faktor demografi seperti: a) umur, b) jenis kelamin, c) latar belakang pendidikan dan d) pengalaman bekerja seseorang diperhitungkan sebagai penentu bagi minat berwirausaha. Faktor lingkungan seperti : a) hubungan sosial, b) infrastruktur fisik dan c) institusional serta d) faktor budaya dapat mempengaruhi minat berwirausaha (Pengaruh Efikasi Diri, Kesiapan Instrumentasi Dan Kebutuhan Akan Prestasi Terhadap Minat Mahasiswa Berwirausaha (Studi Kasus Mahasiswa Departemen Manajemen FE UMSU).

\section{Aspek-Aspek Minat Berwirausaha}

Crow \& Crow dalam Yuwono dkk (2008) menyebutkan ada tiga aspek minat pada diri seseorang, yaitu: a) Dorongan dari dalam untuk memenuhi kebutuhan diri sebagai sumber penggerak untuk melakukan sesuatu; b) Kebutuhan untuk berhubungan dengan lingkungan sosialnya yang akan menentukan posisi individu dalam lingkungannya; Perasaan individu terhadap suatu pekerjaan yang dilakukannya.

Dalam Enterpreneur.s Handbook seperti yang dikutip oleh Wirasasmita dalam Suryana (2006) dikemukakan beberapa alasan yang menumbuhkan minat seseorang menjadi wirausaha yakni: 1) Alasan keuangan; 2) Alasan sosial; 3) Alasan pelayanan; d) Alasan pemenuhan diri.

\section{Konsep Diri}

Teori-teori terdahulu mendefinisikan dan menggunakan konsep diri dalam terminologi yang bersifat umum sebagai persepsi global atas diri sendiri (self worth) atau harga diri (self esteem) (Pajares dan Schunk, 2001). Persepsi yang dimaksud adalah keyakinan, perasaan, dan sikap tentang nilai-nilai yang diakui oleh individu sebagai ciri-ciri dirinya (Hurlock, 1979). Menurut Fuhrmann (1990), konsep diri adalah konsep dasar tentang diri sendiri, pikiran dan opini pribadi, kesadaran tentang apa dan siapa dirinya, dan bagaimana perbandingan antara dirinya dengan orang lain serta bagaimana beberapa idealisme yang telah dikembangkannya. Hal-hal yang termasuk di dalam persepsi diri ini antara lain adalah fisik, seksual, kognitif, moral, okupasional atau segala apapun yang telah dilakukan dengan ketrampilan, peran, kompetensi, penampilan, motivasi, tujuan atau emosi (Fuhrmann, 1990). Sedangkan menurut Brooks (dalam Rachmat, 1999), konsep diri merupakan persepsi terhadap diri individu sendiri, baik yang bersifat fisik, social dan psikologis yang diperoleh melalui pengalaman dari interaksi individu dengan orang lain.

\section{Faktor-Faktor yang Mempengaruhi Konsep Diri}

Konsep diri berkembang dari sejumlah sumber yang saling berkait antara satu sumber dengan sumber yang lain. Menurut Burns (1993), konsep diri dipengaruhi oleh faktor-faktor sebagai berikut: a. Citra diri; b. Kemampuan bahasa; c. Umpan balik dari lingkungan; d. 
Identifikasi dengan peran jenis yang sesuai dengan stereotip masyarakat. e. Pola asuh, perlakuan, dan komunikasi orang tua.

\section{Aspek-Aspek Konsep Diri}

Staines menjelaskan ada tiga aspek dalam konsep diri (Burns, 1993), yaitu: a. Konsep diri dasar; b. Diri sosial; c. Diri ideal. Aspek ini merupakan gambaran mengenai pribadi yang diharapkan oleh individu, sebagian berupa keinginan dan sebagian berupa keharusankeharusan.

Hurlock mengemukakan bahwa konsep diri memiliki dua aspek (1999), yaitu: secara Fisik. Aspek ini meliputi sejumlah konsep yang dimiliki individu mengenai penampilan, kesesuaian dengan jenis kelamin, arti penting tubuh, dan perasaan gengsi di hadapan orang lain yang disebabkan oleh keadaan fisiknya. Hal penting yang berkaitan dengan keadaan fisik adalah daya tarik dan penampilan tubuh dihadapan orang lain. Individu dengan penampilan yang menarik cenderung mendapatkan sikap sosial yang menyenangkan dan penerimaan sosial dari lingkungan sekitar yang akan menimbulkan konsep yang positif bagi individu.

Aspek Psikologis, yaitu Aspek yang meliputi penilaian individu terhadap keadaan psikis dirinya, seperti rasa percaya diri, harga diri, serta kemampuan dan ketidakmampuannya. Penilaian individu terhadap keadaan psikis dirinya, seperti perasaan mengenai kemampuan atau ketidakmampuannya akan berpengaruh terhadap rasa percaya diri dan harga dirinya. Individu yang merasa mampu akan mengalami peningkatan rasa percaya diri dan harga diri, sedangkan individu dengan perasaan tidak mampu akan merasa rendah diri sehingga cenderung terjadi penurunan harga diri.

\section{SIMPULAN}

Ada hubungan yang signifikan antara konsep diri dengan minat wirausaha pada mahasiswa Universitas Medan Area. Adapun koefisien determinan $\left(\mathrm{r}^{2}\right)$ dari korelasi di atas adalah sebesar $\mathrm{r}^{2}$ $=0,206$. Hal ini menunjukkan bahwa minat wirausaha dibentuk oleh konsep diri dansebesar 20,6\%. Konsep diri yang ada pada mahasiswa Universitas Medan Area tergolong rendah, dimana dari 372 sample orang yang diteliti sebanyak 224 orang sampel atau 60,2\%. Dari total sampel yang ada.

\section{DAFTAR PUSTAKA}

As'ad, M. (1991). Psikologi Industri. Yogyakarta. Liberty.

Susanto, A. (2002). Kewiraswataan. Penerbit Ghalia Indonesia. Jakarta.

Azwar, S. (2010). Penyusunan Skala Psikologi. Yogyakarta: Penerbit Pustaka Pelajar. (2007). Metode Penelitian, Yogyakarta: Pustaka Pelajar. (2000). Reliabilitas dan Validitas. Yogyakarta: Penerbit Pustaka Pelajar.

Burns, R. (1982). Self-Concept Development And Education. London: Holt, Rinehart and Wiston

Burns, R.B. (1993). Konsep Diri (Teori, Pengukuran, Perkembangan, dan Perilaku). Alih bahasa: Eddy. Jakarta: Arcan.

Crow, L \& Crow, A. (1989), "Psychology Pendidikan“, Yogyakarta: Nurcahya

Crow and Crow. (1975). An Outline of General Psykology. New York: Lithe fred adam and co.

Firdaus S. (2012) : “Pengaruh Prestasi Praktik Kerja Industri, Prestasi Mata pelajaran Kewirausahaan, Dan Konsep Diri Terhadap Minat Berwirausaha Siswa Kelas XII SMK Negeri 1 Kandeman Batang Tahun Ajaran 2011/2012". Skripsi Program Studi Pendidikan Teknik Elektro Fakultas Teknik Universitas Negeri Yogyakarta. 2012.

Hurlock, E.B. (1999). Psikologi Perkembangan: Suatu Pendekatan Sepanjang Rentang Kehidupan. Alih bahasa: Istiwidayati \& Soedjarwo. Edisi Kelima. Jakarta: Erlangga.

Henry, I. [2013], Pengaruh Pendidikan, Konsep Diri, Dan Motivasi Berwirausaha Terhadap Minat Berwirausaha Pada Mahasiswa Di Wilayah Kota Depok Skripsi http://library.gunadarma.ac.id/repository/view/3754166/pengaruh-pendidikan-konsepdiri-dan-motivasi-berwirausaha-terhadap-minat-berwirausaha-pada-mahasiswa-di-wilayah-kotadepok.html/ 
Mulyana, M. (2011). Analisis Pengaruh Faktor Personal dan Lingkungan Eksternal Terhadap Minat Berwirausaha Mahasiswa STIE Kesatuan Bogor.

Rini. J.F. (2002). Konsep Diri. (www.e-psikologi.com)

Hantoro, S. (2005). Kiat Sukses Berwirausaha. Yogyakarta: Adi Karya Nusa.

Sobur, A. (2003). Psikologi Umum. Bandung. Pustaka Setia.

Slameto. (2003). Belajar dan Faktor-faktor yang Mempengaruhinya. Jakarta: PT. Rineka Cipta.

Robbins, S.P. Judge, T.A. (2008). Perilaku Organisasi Buku 1, Jakarta: Salemba Empat

Ritonga, A.R. (2011). Pengaruh Efikasi Diri, Kesiapan Instrumentasi dan Kebutuhan Akan Prestasi Terhadap Minat Mahasiswa Berwirausaha (Studi Kasus Mahasiswa Departemen Manajemen FE UMSU), Medan: Skripsi USU.

Putra, R.A. (2012). "Faktor-faktor Penentu Minat Mahasiswa Manajemen Untuk Berwirausaha" Jurnal Manajemen, Volume 01, Nomor 01, September 2012.

Brooks, W.D., Emmert, P. (1976). Interpersonal Community. Iowa. Brow Company Publisher.

Walgito, B, (2003), Psikologi sosial (suatu pengantar), ed.IV, Yogyakarta: C.V.Andi offset.

Winkel, W. S. (1999). Psikologi Pengajaran, Cetakan II. Jakarta: Gramedia

(http://ekonomi.kompasiana.com/wirausaha/2013/11/07/tahun-2013-pengangguran-di-indonesiamelonjak-605967.html)

(http://moebarak.wordpress.com/2011/12/05/minat-berwirausaha/) (Desember 2011, akses 25 Januari 2014)

http://rohadieducation.wordpress.com/2010/06/04/karakteristik-wirausaha/. 